\title{
The In Vitro Synthesis and Processing of the Branched-Chain Amino Acid Binding Proteins
}

\author{
Charles J. Daniels, James J. Anderson, Robert Landick, and Dale L. Oxender \\ Department of Biological Chemistry, University of Michigan, Ann Arbor, Michigan 48109
}

\begin{abstract}
The synthesis of the leucine-specific and LIV-binding proteins was examined in vitro in a coupled transcription/translation system using the hybrid plasmids pOX7 and pOX13 as templates. Plasmid pOX7 contains the liv $K$ gene coding for the leucine-specific binding protein, and pOX13 contains the liv $J$ gene coding for the LIV-binding protein. Both binding proteins were synthesized in vitro as precursor forms with molecular weights approximately 2,500 greater than their respective mature forms. Conversion of the precursor forms to their mature forms occurred during post-translational incubation following synthesis in the presence of membrane. The precursor of the LIV-binding protein was processed more rapidly than the leucine-specific binding protein precursor. Processing activity could be removed from the in vitro synthesis system by centrifugation, suggesting that the processing activity was membrane associated. Restoration of post-translational processing activity was achieved by adding inside-out membrane vesicles to membrane-depleted reaction mixtures.
\end{abstract}

Key words: in vitro synthesis, branched-chain amino acid binding proteins, precursors, processing, periplasmic proteins

The branched-chain amino acid binding proteins coded for by the liv $J$ and livK genes [1] are components of the high-affinity leucine transport system of Escherichia coli. These proteins are located in the periplasmic space of the bacteria and, therefore, are secreted proteins. Current models for the synthesis of secreted proteins [2,3] suggest that these proteins are produced as precursor forms containing an $\mathrm{N}$-terminal amino acid extension. During the process of secretion the N-terminal amino acid extensions are removed by a membrane-associated enzyme. Recently we have cloned the genes for the high-affinity leucine transport system for E coli [4]. Subcloning the $2.1 \mathrm{~kb} \mathrm{Bgl} \mathrm{II} \mathrm{fragment} \mathrm{from} \mathrm{the}$ parental plasmid, pOX1, into the Bam HI site of pBR322 provided us with the hybrid plasmid, pOX7 [5]. This plasmid contained the liv $K$ gene, the structural gene for the leucine-specific binding protein [5]. Subcloning of the $4.5 \mathrm{~kb}$ Hind III/Bam HI fragment of pOX1 into similarly cut pBR322 produced another hybrid plasmid, pOX13 [6]. The pOX13 plasmid contains the livJ gene coding for the LIV-binding protein [6]. Through

James J. Anderson is now at the Genex Corp., Rockville, MD 20852.

Received June 16, 1980; accepted September 21, 1980. 
the use of a cell-free protein synthesis system programmed by pOX7 and pOX13 DNA we have examined the synthesis of precursors of the two closely related periplasmic binding proteins and the processing of these precursors.

\section{MATERIALS}

Materials for polyacrylamide gels were obtained from Bio-Rad Laboratories. RNasefree sucrose and deoxyribonuclease II were from Sigma. Ribonuclease was obtained from Miles Laboratories. L- $\left[{ }^{35} \mathrm{~S}\right]$ methionine, $600 \mathrm{Ci} / \mathrm{mmole}$, was obtained from Amersham.

\section{METHODS}

\section{Cells}

In this study the $\mathrm{RNase}^{-}$strain $\mathrm{AE} 1\left(\mathrm{rNS}^{-} \mathrm{X}^{-} \Delta\right.$ ton $\mathrm{B} \operatorname{trp} \mathrm{AE} 1 \operatorname{trpR^{-}}$ ) [7] was used in the preparation of S-30, S-100, and ribosomes.

\section{Cell-Free Protein Synthesis}

Proteins were labeled with $\mathrm{L}-\left[{ }^{35} \mathrm{~S}\right]$ methionine by two different coupled transcription/ translation systems, one that contained membrane material (S-30) and one that was membrane free ( $\mathrm{S}-100$ plus ribosomes). The $\mathrm{S}-30$ fractions and the reaction mixtures were prepared as described by Zubay [8] with slight modification [9]. Plasmid DNA used as the template was isolated from transformed strains [9] and purified by cesium chloride gradient centrifugation [10]. Synthesis was terminated with the addition of DNase (250 $\mu \mathrm{g} / \mathrm{ml})$, RNase $(250 \mu \mathrm{g} / \mathrm{ml})$, and unlabeled methionine.

For the preparation of membrane-free reaction mixtures (S-100) the S-30 preparations were centrifuged at $100,000 \mathrm{~g}$ for $2 \mathrm{~h}$, and only the upper two-thirds of the supernatant fraction was retained. The S-100 fraction was devoid of membranes as indicated by the loss of NADH oxidase activity, an inner membrane marker enzyme [11]. Membrane-free ribosomes were prepared by the procedure described by Godson and Sinsheimer [12] with slight modification. One liter of cells were grown in Luria Broth at $37^{\circ} \mathrm{C}$ to an $\mathrm{A}_{600}$ of 0.8 . The cell suspension was cooled slowly on ice $(15 \mathrm{~min})$. Cells were harvested and resuspended in $10 \mathrm{ml}$ of ice-cold sucrose $25 \%(\mathrm{w} / \mathrm{v})$ in $50 \mathrm{mM}$ Tris- $\mathrm{HCl} \mathrm{pH} 8.1$. After cooling on ice for $2 \mathrm{~min}, 1 \mathrm{ml}$ of lysozyme $(6.4 \mathrm{mg} / \mathrm{ml})$ in $50 \mathrm{mM}$ Tris-HCl pH 8.1 and $1 \mathrm{ml}$ of EDTA (20 $\mathrm{mg} / \mathrm{ml}$ ) were added. Following incubation on ice for $2 \mathrm{~min}$ this mixture was pipetted into

Fig. 1. In vitro synthesis of proteins coded by pOX7 and pOX13 DNA. L- $\left[{ }^{35} \mathrm{~S}\right]$ methionine-labeled proteins produced during $45 \mathrm{~min}$ of synthesis by a S-30 containing reaction mixture were separated by SDS-polyacrylamide electrophoresis. Dried gels were autoradiographed Lane 1, the plasmid vector pBR322; lane 2, pOX7; and lane 3, pOX13. The positions of mature leucine-specific (LS) and LIVbinding (LIV) proteins are indicated.

Fig. 2. The effects of postsynthetic incubation on the processing of precursor forms. Labeled proteins were synthesized in a S-30 containing reaction for $45 \mathrm{~min}$. Following termination of synthesis by addition of DNase, RNase, and an excess of unlabeled methionine the reaction mixtures were split. One half of the mixture was combined with SDS-sample buffer and boiled (no postsynthetic incubation). The remaining half was allowed to continue incubation at $37^{\circ} \mathrm{C}$. Proteins were separated by SDS-polyacrylamide gel electrophoresis as described in Methods. The fixed and dried gels were then autoradiographed. Lane 1, pOX7, no postsynthetic incubation; lane 2, pOX7, $60 \mathrm{~min}$ postsynthetic incubation; lane 3 , pOX13, no postsynthetic incubation; and lane 4, pOX13, $60 \mathrm{~min}$ postsynthetic incubation. Positions of mature forms of the binding proteins are indicated. 
a solution containing $1.5 \mathrm{ml}$ of Brij $355 \%(\mathrm{w} / \mathrm{v})$ in $10 \mathrm{mM}$ Tris-HCl pH 7.2 and $1.5 \mathrm{ml}$ of $0.125 \mathrm{M} \mathrm{MgSO}_{4}$. The resulting suspension was mixed gently at room temperature for $10 \mathrm{~min}$. The lysate was centrifuged at $4^{\circ} \mathrm{C}$ in a Beckman $50 \mathrm{Ti}$ rotor at $42,000 \mathrm{rpm}$ for $5 \mathrm{~min}$. The supernatant fluid was removed and centrifuged again at 42,000 rpm for $5 \mathrm{~min}$. The supernatant fluid was removed and centrifuged again at $42,000 \mathrm{rpm}$ for $60 \mathrm{~min}$ to pellet the ribosomes. The resulting pellet was resuspended with $0.2 \mathrm{ml}$ of $10 \mathrm{mM}$ Trisacetate $\mathrm{pH} 8.2,10 \mathrm{mM} \mathrm{Mg}$ acetate, and $1 \mathrm{mM}$ dithiothreitol. Small portions $(25 \mu \mathrm{l})$ were stored frozen at $-70^{\circ} \mathrm{C}$. Optimal concentrations of ribosomes and $\mathrm{Mg}^{+2}$ for in vitro synthesis were determined for each preparation.
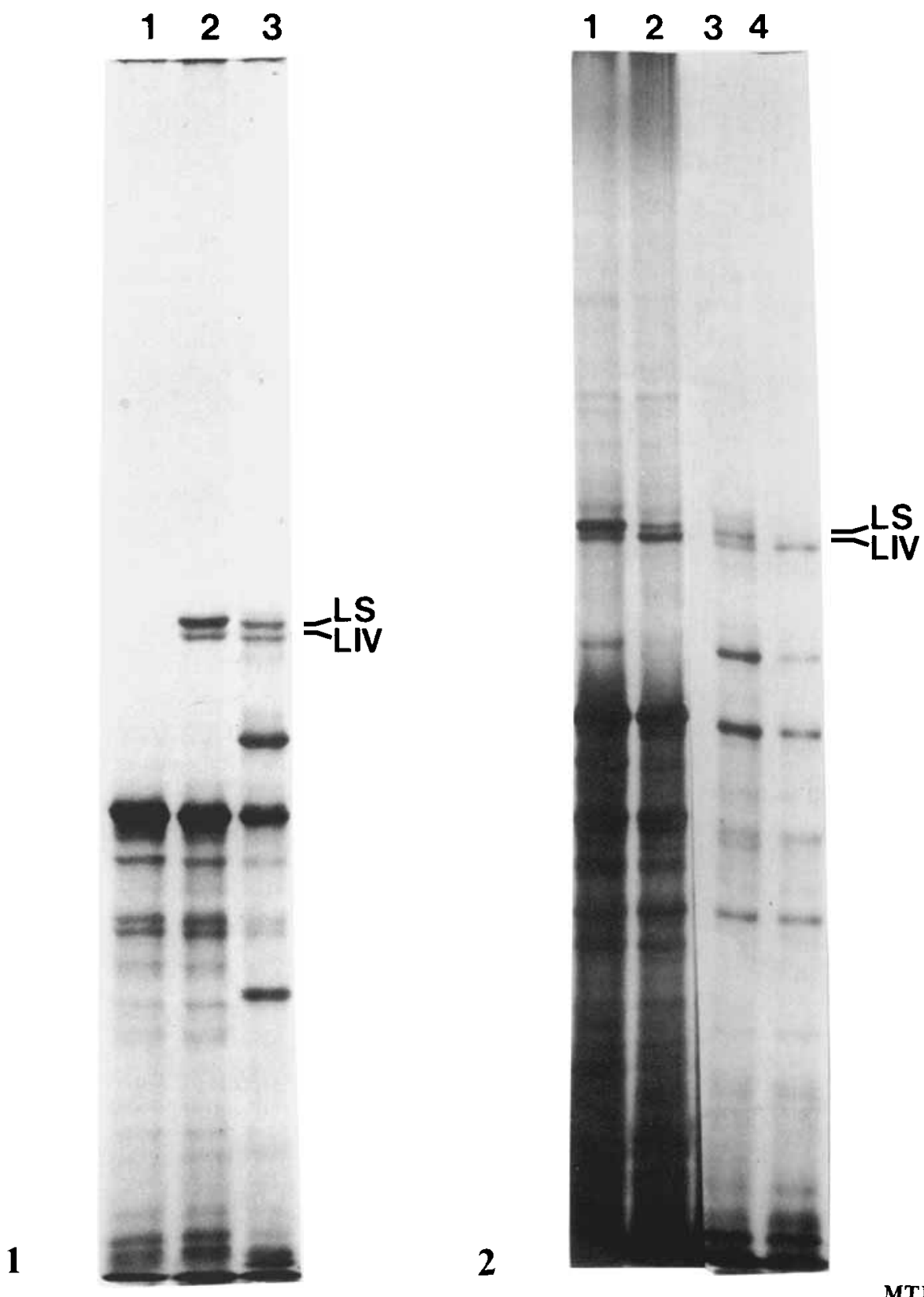


\section{Membrane Preparations}

Inside out membrane vesicles were prepared from strain $\mathrm{AE} 1$ as described by Chang et al [13], except that triethanolamine buffers were replaced by Tris-acetate buffers at $\mathrm{pH} 8.2$.

\section{Polyacrylamide Gel Electrophoresis}

Samples of in vitro reaction mixtures were combined with SDS-sample buffer [14] and boiled for $5 \mathrm{~min}$ prior to electrophoresis. Slab gels containing $12.5 \%$ acrylamide and $0.1 \%$ SDS were prepared as described by Laemmli [14]. Gels were fixed and stained in a solution containing methanol $50 \%(\mathrm{v} / \mathrm{v})$, acetic acid $10 \%(\mathrm{v} / \mathrm{v})$, and Commassie blue $0.1 \%$ $(\mathrm{w} / \mathrm{v})$. The gels were destained in $10 \%$ acetic acid, dried on filter paper, and autoradiographed.

\section{RESULTS}

\section{In Vitro Expression of pOX7 and pOX13}

We have described previously the cloning of a $13 \mathrm{~kb}$ EcoR1 DNA fragment which contained the 4 known high-affinity branched-chain amino acid transport genes [4]. Two of the subcloning strategies applied to the parental plasmid pOX1 led to the isolation of hybrid plasmids, each containing one of the binding protein genes. The pOX7 plasmid contains the livK gene, and the pOX13 plasmid contains the liv $J$ gene, which code for the leucine-specific and LIV-binding proteins, respectively.

When pOX7 DNA was used as a template for in vitro protein synthesis in an S-30 reaction mixture, two proteins related to the leucine-specific binding protein were produced (Fig. 1). The larger protein has an apparent molecular weight of 42,000 and has been identified as the leucine-specific binding protein precursor [5]. The second protein has an apparent molecular weight identical to the leucine-specific binding protein. Protein synthesis directed by the pOX13 plasmid produced 2 proteins related to the LIV-binding protein with apparent molecular weights of 40,000 and 38,000 (Fig. 1). The former protein is the presumed precursor of the LIV-binding protein, while the latter has a molecular weight identical to mature LIV-binding protein. The identity of these proteins was further verified by their cross-reactivity with antibodies specific for the mature branched-chain amino acid binding proteins (data not shown). Complementation analysis [6] showed that positive complementation of liv $K$ mutations was observed when strains were transformed with the pOX7 plasmid. Similarly, pOX13 complemented only liv $J$ binding protein mutations [6].

Fig. 3. The effects of postsynthetic incubation on the precursor forms synthesized in an S-100 containing reaction. Conditions were the same as that described in Figure 2. Lane 1, pOX7 no postsynthetic incubation; lane 2, pOX7, 60 min postsynthetic incubation; lane 3, pOX13, no postsynthetic incubation; and lane 4, pOX13, 50 min postsynthetic incubation. Positions of the mature binding proteins are indicated.

Fig. 4. Post-translational processing of the leucine-specific binding protein precursor by membrane preparation. $\mathrm{L}-\left[{ }^{35} \mathrm{~S}\right]$ methionine-labeled proteins were synthesized in a $\mathrm{S}-100$ containing reaction mix ture with pOX7 DNA as template. After 60 min of synthesis the reaction was terminated with DNase, RNase, and unlabeled methionine. Portions of the reaction mixture were combined with an equal volume of $\mathrm{H}_{2} \mathrm{O}$ (lane 1 ) or inside-out membrane vesicles $(0.13 \mathrm{mg}$ protein $/ \mathrm{ml}$ ) (lane 2 ). Incubation was continued for $60 \mathrm{~min}$ at $37^{\circ} \mathrm{C}$. The products were analyzed by SDS-polyacrylamide gel electro phoresis followed by autoradiography of the dried gel. The position of mature leucine-specific binding protein is indicated. 


\section{Processing of Precursor Forms}

In vitro synthesis using the S-30 system produced precursor and mature forms of both binding proteins (Fig. 1), indicating the presence of processing activity in the S-30 fraction. During the synthesis period there is a slight amount of processing of the leucinespecific binding protein precursor, and considerable processing of the LIV-binding protein occurs. We had observed previously that continued incubation of the in vitro synthesis mixture for $1 \mathrm{~h}$ following termination of synthesis produced additional processing of the leucine-specific binding protein [5]. This postsynthetic processing was also observed for the LIV-binding protein (Fig. 2).
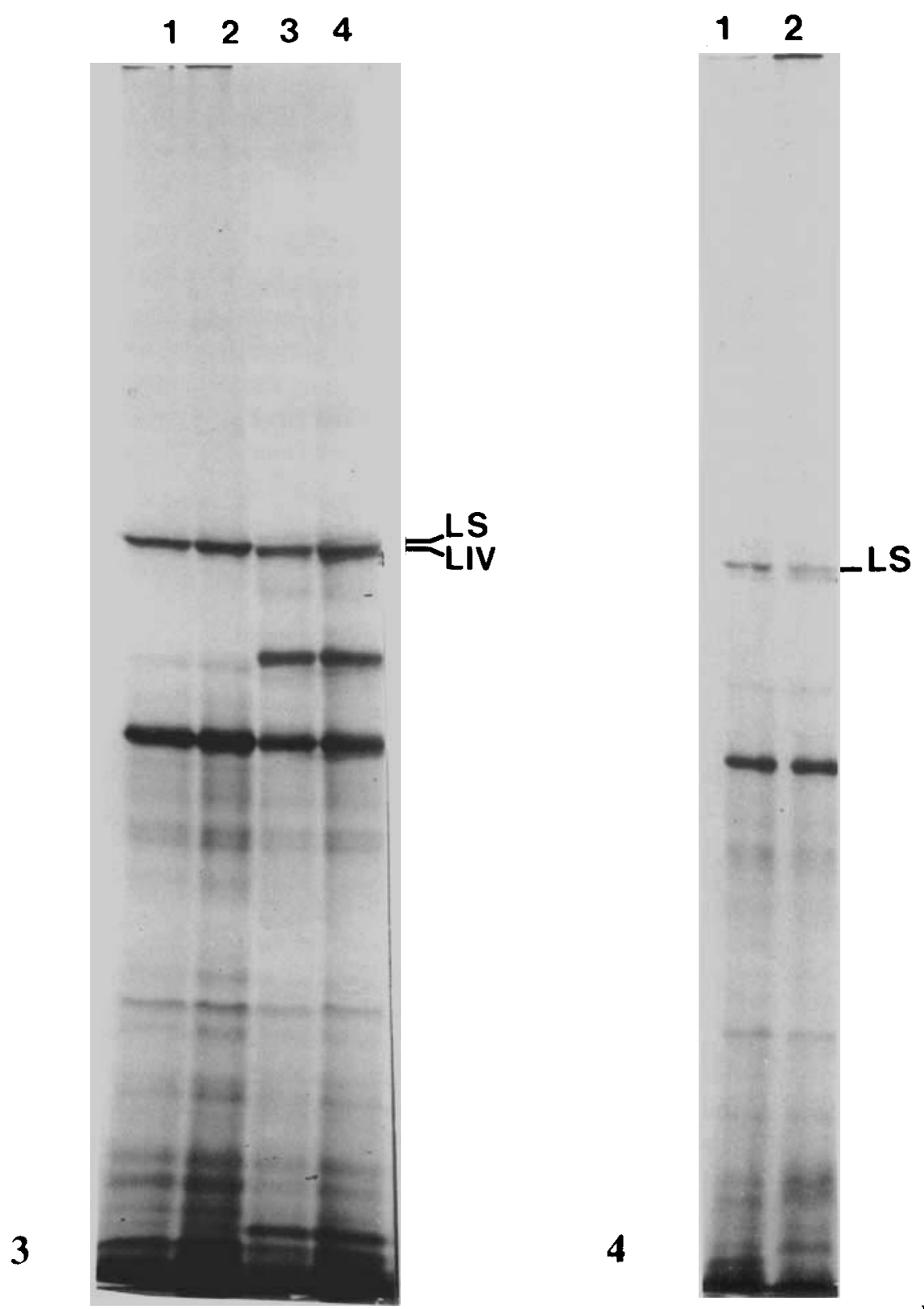
The reported membrane association of processing activity [15-19] suggests that the processing activity in the S-30 fraction may be due to the presence of membrane in the preparations (see Methods). To verify the membrane association of the processing activity a membrane-free in vitro protein-synthesizing system was sought. This system was established by removing membrane material and ribosomes from the S-30 fraction. As described in Methods, S-100 fraction was prepared and supplemented with membrane-free ribosomes. Figure 3 demonstrates that the removal of membrane from the reaction mixture eliminated the processing activity observed during the synthetic period and post-translationally.

This S-100 system was used to determine whether exogenously added membrane preparations contained processing activity. Large amounts of inverted membrane vesicle preparations added during the synthesis period severely decreased the amount of label incorporated into proteins. When membrane vesicles $(0.13 \mathrm{mg}$ protein $/ \mathrm{ml})$ were added posttranslationally an increase in the processing of the leucine-specific binding precursor was observed (Fig. 4). Whether this post-translational processing is accompanied by translocation of the binding protein into the membrane vesicles, as might be predicted by the membrane trigger hypothesis [3], has not been established.

\section{Inhibition of Processing}

The processing activity observed in reaction mixtures containing a $S-30$ fraction could not be inhibited by the protease inhibitors phenylmethyl sulfonyl fluoride; trypsin inhibitors from soybean, eggwhite, and lima bean; or aprotinin. Similarly, the membraneperturbing agents procaine and tetracaine had no effect. Ethanol slightly inhibited processing; however, methanol and acetonitrite had no effect. Dipeptides that were represented in the signal peptide sequence of the leucine-specific binding protein [5] such as methionylalanine or the dipeptide that spans the processing site, alanylaspartate, had no effect on processing.

\section{DISCUSSION}

The two plasmids pOX7 and pOX13 subcloned from the parental plasmid pOX1 both carry the gene for one of the leucine-binding proteins. pOX7 carries the livK gene coding for the leucine-specific binding protein, and pOX13 carries the liv $J$ gene coding for the LIV-binding protein. Precursor forms of both binding proteins were detected when pOX7 or pOX13 DNA were used to program an in vitro coupled transcription/translational system (Fig. 1). The production of precursor forms of these periplasmic proteins is in agreement with the hypothesis that prokaryotic membrane and secreted proteins are made as larger precursor forms similar to that observed for many eukaryotic secreted and membrane proteins $[2,20]$. The precursor forms of the two binding proteins are processed to proteins that have molecular weights identical to their respective mature forms. Previous reports describing processing activity in $\mathrm{E}$ coli indicated that this activity was membrane associated [15-19]. The processing activity acting on these periplasmic binding protein precursors appears also to be membrane associated. Efficient processing could be observed by first synthesizing the precursors in vitro for $60 \mathrm{~min}$ with the membranecontaining S-30 fractions and then allowing post-translational processing by incubating the reaction mixture for an additional $60 \mathrm{~min}$ (Fig. 2). The removal of membrane from the reaction mixture by preparing a $S-100$ fraction permitted synthesis of the precursor forms without producing significant processing (Fig. 3). The addition of membrane preparations following synthesis of the precursors produced post-translational processing (Fig. 4). We have not been able to demonstrate increased processing or sequestering when 
exogenous membrane preparations are added to S-100 containing reactions during synthesis due to severe inhibition of synthesis. Addition of membrane vesicles following synthesis in S-100 containing reactions does, however, increase processing. Translocation into intact vesicles under these conditions has not been determined.

We have observed a significant difference in the efficiency in the processing of the two binding protein precursors. The mature proteins have $80 \%$ homology [21] in their amino acid sequences, which suggests that they are a result of a gene duplication. In spite of this homology in the primary structure of the mature forms, their signal peptide sequences have only $60 \%$ homology [5; R.C. Landick unpublished data]. The difference in amino acid sequence of the signal region is presumably the basis for this difference in processing efficiencies.

Attempts are being made in this and other laboratories to isolate leader peptidase activity from $E$ coli membranes to determine whether a single enzyme is responsible for processing more than one or several precursor proteins. We have observed that when purified leader peptidase active on M13 precoat protein (kindly provided to us by C. Zwizinski and $W$. Wickner) was present during synthesis in a S-100 containing reaction the LIV. binding protein was completely processed to its mature form. Processing of the leucinespecific binding protein was also increased significantly. Studies are under way to confirm the fidelity of these processing events.

\section{REFERENCES}

1. Anderson JJ, Oxender DL: J Bacteriol 130:384, 1977.

2. Blobel G, Dobberstein B: J Cell Biol 67:835, 1975.

3 Wickner W: Annu Rev Biochem 48:23, 1979.

4. Oxender DL, Anderson JJ, Daniels CJ, Landick R, Gunsalus RP, Zurawski G, Selker E, Yanofsky C: Proc Natl Acad Sci USA 77:1412, 1980.

5. Oxender DL, Anderson JJ, Daniels CJ, Landick R, Gunsalus RP Zurawski G, Yanofsky C: Proc Natl Acad Sci USA 77:2005, 1980.

6. Landick R, Anderson JJ, Mayo MM, Gunsalus RP, Daniels CJ, Oxender DL: J Supramol Struct (in press).

7. Zalkin H, Yanofsky C, Squires CL: J Biol Chem 249:465, 1974.

8. Zubay G: Annu Rev Genet 11:267, 1977.

9. Gunsalus RP, Zurawski G, Yanofsky C: J Bacteriol 140:106, 1979.

10. Clewell DB, Helinski DR: Proc Natl Acad Sci USA 62:1159 1969.

11. Osborn MJ, Gander JE, Parisi E, Carson J: J Biol Chem 247:3962, 1972.

12. Godson GN, Sinsheimer RL: Biochem Biophys Acta 149:476, 1967.

13. Chang NC, Model P, Blobel G: Proc Natl Acad USA 76:1251, 1979.

14. Laemmli UK: Nature 227:680, 1970.

15. Inouye H, Beckwith J: Proc Natl Acad Sci USA 74:1440 1977.

16. Chang NC, Blobel.G, Model P: Proc Natl Acad Sci USA 75:361, 1978.

17 Randall LL, Josefsson LG, Hardy SJS: Eur J Biochem 92:411, 1978.

18. Mandell G, Wickner W: Proc Natl Acad Sci USA 76:236, 1979.

19. Chang CN, Inouye H, Model P, Beckwith J: J Bacteriol 142:726, 1980.

20. Inouye M, Halegoua S: CRC Crit Rev Biochem (in press).

21. Ovchinnikov YA, Aldanova NA, Grinkevich VA, Arzamazova NM, Moroz IN, Nazimov, IV: Bioorg Chem USSR 3:564, 1977. 